Cakrawala Dini: Jurnal Pendidikan Anak Usia Dini | p-ISSN 2087-I317 | e-ISSN 2621-8321

Vol. II. No.2 November 2020 | Hal 88-95

\title{
PELAKSANAAN PENILAIAN AUTENTIK GURU PENDIDIKAN ANAK USIA DINI
}

\author{
Wahyu Hidayat ${ }^{1}$, Andriani ${ }^{2}$ \\ ${ }^{1}$ IAIN Parepare, ${ }^{2}$ Universiti Kebangsaan Malaysia
}

\begin{abstract}
Authentic assessment is a systematic method for obtaining information through naturalistic observations that assess or measure children's achievement and progress and development. Authentic assessment aims to design individual children's learning by identifying specific needs, assistance or services. Written assessments such as written examinations or oral examinations do not fit the cognitive development of early childhood. Authentic assessment aims to compensate for an overemphasis on written examinations. Some research on authentic assessment focuses more on primary and secondary schools, whereas authentic assessment is very appropriate at the level of early childhood education. This study aims to identify the authentic assessment of Early Childhood Education (PAUD) teachers and identify the practice of authentic assessment of early childhood education teachers in North Aceh based on the domain of child development. The results of the questionnaire showed $85,71 \%$ PAUD teachers have not fully implemented authentic assessment and have not applied the concept of a comprehensive child development domain in the assessment process. Therefore, teachers need to better understand the principles and procedures for authentic assessment.
\end{abstract}

Keyword: Authentic Assessment; Early Childhood Education; Teacher

\begin{abstract}
Abstrak: Penilaian autentik adalah metode sistematis untuk memperoleh informasi melalui pengamatan naturalistik yang menilai atau mengukur prestasi dan kemajuan serta perkembangan anak. Penilaian autentik bertujuan untuk merancang pembelajaran individu anak-anak dengan mengidentifikasi kebutuhan, bantuan atau layanan tertentu. Penilaian tertulis seperti ujian tulis atau ujian lisan tidak sesuai dengan perkembangan kognitif anak usia dini. Penilaian autentik bertujuan untuk mengimbangi penilaian yang terlalu menekankan kepada ujian tertulis. Beberapa penelitian tentang penilaian autentik lebih memfokuskan pada sekolah dasar dan menengah, padahal penilaian autentik sangat sesuai pada tingkat pendidikan anak usia dini. Penelitian ini bertujuan untuk mengidentifikasi penilaian autentik guru Pendidikan Anak Usia Dini (PAUD) dan mengidentifikasi praktik penilaian autentik guru pendidikan anak usia dini di Aceh Utara berdasarkan domain perkembangan anak. Hasil kuesioner menunjukkan $85,71 \%$ guru PAUD belum menerapkan sepenuhnya penilaian autentik dan belum menerapkan konsep domain perkembangan anak yang komprehensif dalam proses penilaiannya. Oleh itu, guru perlu lebih memahami lagi tentang prinsip dan tata cara penilaian autentik.
\end{abstract}

Kata Kunci: Penilaian Autentik, Guru Pendidikan Awal Kanak-Kanak

\footnotetext{
I IAIN Parepare, Email: wahyuhidayat国iainpare.ac.id

${ }^{2}$ Universiti Kebangsaan Malaysia, Email: andriani.bintinurdin
} 


\section{PENDAHULUAN}

Penilaian merupakan proses penting dalam aktivitas pembelajaran untuk memastikan tujuan pembelajaran telah tercapai atau belum. Mulyasa (2012) menyatakan penilaian merupakan proses pengumpulan laporan dan penggunaan informasi tentang hasil belajar kanak-kanak dengan menerapkan prinsip-prinsip penilaian, berkelanjutan, bukti-bukti autentik, ketepatan dan konsisten.

Menurut Shamsuri (2008), penilaian bertujuan untuk memantau dan mengetahui keberhasilan dan pengaruh program yang telah dilaksanakan serta bagian dari proses pembelajaran dan pengajaran. Dalam hal ini proses pembelajaran di lembaga Pendidikan Anak Usia Dini (PAUD). Penilaian dalam PAUD di Indonesia merupakan upaya mengumpulkan, menganalisis, dan menafsirkan pelbagai informasi mengenai kemajuan pelbagai aspek perkembangan anak setelah mengikuti aktivitas pembiasaan dalam masa tertentu (Kementerian Pendidikan Indonesia 2010). Dalam konteks penilaian PAUD memiliki karakteristik perkembangan yang berbeda-beda.

The National Association for the Young Children (NAEYC) telah merumuskan tujuan penilaian yaitu pertama, merencanakan anak-anak dalam proses pembelajaran individual dan kelompok agar dapat berkomunikasi dengan orang tuanya. Kedua, mengidentifikasikan anak-anak yang memerlukan bantuan atau layanan khusus dari guru dan sekolah. Ketiga, menilai apakah tujuan pendidikan yang direncanakan sudah tercapai atau belum. Koralek (2004), menyatakan The National Association for the Young Children (NAEYC) dan The National Association of Early Childhood Specialist in State Department of Education (NAECS/SDE) menegaskan penilaian adalah suatu sistem kaidah yang sistematis bagi memperoleh informasi dengan pengamatan, anekdot, check list, proyek, dan portfolio.

Guru sebagai pihak yang bertanggung jawab dalam penilaian. Oleh itu, kualitas pelaksanaan guru yang berkaitan dengan penilaian amat perlu mendapat perhatian. Guru harus mempunyai kemahiran penilaian bagi melaksanakan penilaian yang berkesan. Guru dianjurkan menggunakan pelbagai teknik penilaian yang berkesan dan sesuai dengan perkembangan anak. Sistem pendidikan di Indonesia yang berorientasikan ujian kini diubah secara bertahap setiap tahunnya. Dengan ini, satu sistem penilaian baru diperkenalkan yakni berbentuk holistik agar dapat memenuhi prinsip dan tujuan pendidikan. Kini, berkembang dikalangan orang tua berpendapat bahwa ujian tertulis tidak sesuai lagi digunakan dalam sistem pendidikan terutama dalam pendidikan anak usia dini. Ini karena, terdapat ketidakadilan dari segi item ujian yang bersandarkan kepada norma dan pengalaman kelompok tertentu dalam masyarakat yang dapat mempengaruhi validitas suatu ujian (Stallman \& Pearson, 1990).

Penilaian autentik penting untuk memastikan perkembangan pembelajaran anak-anak, karena aspek tersebut telah menjadi satu aspek yang kritis dan perlu dilakukan pendalaman-pendalaman berbentuk ilmiah. Karena dampaknya yang besar, khususnya kepada anak-anak itu sendiri dan kepada guru yang mendidik, serta orang tua. Kemajuan dan perkembangan pembelajaran mereka terlihat dan terkawal. Hal ini secara tidak langsung dapat memberi umpan balik tentang perihal kesesuaian pendekatan, teknik, kaidah, strategi maupun kurikulum yang digunakan oleh guru dalam mendidik anak-anak (Paasche, Gorril \& Strom, 2004).

Penilaian dalam pendidikan anak usia dini berdasarkan kurikulum 2013 harus dilakukan secara autentik dengan pelbagai aktivitas yang nyata, fungsional 
dan natural (Suyanto, 2005). Jamaris (2004) dan Suyanto (2005), berpendapat penilaian autentik sesuai dengan perkembangan anak-anak pada pendidikan anak usia dini. Menurut Mueller (2006), penilaian autentik merupakan penilaian secara langsung dan ukuran langsung. Seterusnya beliau berpendapat, dengan penilaian autentik banyak aktivitas yang lebih jelas apabila diamati secara langsung dengan menggunakan pengamatan. Penilaian autentik memberi kesempatan kepada anak-anak untuk menampilkan perkembangannya secara alami, efektif dan kreatif (Mueller, 2006; Stiggins, 1994).

Penilaian yang menekankan terhadap tes tulis merupakan awal dari gagasan penilaian autentik. Sebagian pakar mengkritik terhadap penilaian yang menekankan pada ujian tertulis (Gronlund \& James, 2005). Oleh itu, penilaian autentik bertujuan untuk mengimbangi penilaian yang terlalu menekankan kepada ujian tertulis (Gronlund \& James, 2005).

$$
\text { Penilaian autentik telah }
$$

dilaksanakan di negara-negara maju seperti Finlandia dan Amerika Serikat. Begitu pula di Indonesia, penilaian autentik telah menjadi ketetapan dari Kementerian Pendidikan Nasional bahwa penilaian yang digunakan untuk peringkat pendidikan awal kanak-kanak adalah penilaian autentik (Kementerian Pendidikan Nasional 2015). Meskipun Kementerian Pendidikan menekankan perlunya para pendidik menggunakan penilaian autentik tetapi masih ada pendidik di Indonesia yang menggunakan penilaian tradisional (Nurgiyantoro, 2011). Menurut Mahmudah (2016) menyebutkan sebagian besar guru pendidikan anak usia dini tidak tertarik dan tidak mau menggunakan penilaian autentik.

Dalam konteks kajian kurikulum 2013, Aiman (2015) menyebutkan guru masih belum sepenuhnya melakukan perencanaan penilaian autentik secara baik dan pelaksanaan penilaian autentik sesuai kurikulum 2013 masih belum sepenuhnya diimplementasikan terutama dalam hal penggunaan instrumen yang sesuai dengan prosedur penilaian autentik. Padahal menurut penelitian Mahmudah (2016) menyebutkan proses penilaian autentik di PAUD dapat dengan penilaian harian dengan menggunakan pengumpulan data, kompilasi data mingguan, kompilasi data bulanan dan laporan perkembangan anak.

Penelitian yang berkaitan dengan penilaian autentik di Indonesia lebih memfokuskan kepada objek sekolah dasar dan sekolah menengah seperti penelitian Arif, 2014; Cahyadi et al., 2014, Hadikusoma, 2015, Nurjananto \& Kusumo, 2015, Munawati, 2017, Sujati, 2013. Penelitian-penelitian tersebut pula lebih menitik beratkan kepada penelitian tentang penilaian autentik untuk mata pelajaran tertentu. Padahal pada tingkat PAUD sangat digalakkan untuk melaksanakan penilaian autentik. Penelitian penilaian autentik pernah dilaksanakan di Pidie Aceh oleh Ruslan et al (2016). Tetapi penelitian ini lebih memfokuskan pada penelitian tentang kendala dan hambatan yang dihadapi oleh guru PAUD.

Berdasarkan beberapa penjelasan di atas, maka isu permasalahan dalam penelitian ini adalah guru masih belum melaksanakan penilaian autentik secara maksimal (Mahmudah, 2016). Begitu pula pelaksanaan penilaian autentik guruguru PAUD di Aceh Utara kurang diketahui. Oleh itu, penelitian ini dilaksanakan sebagai satu usaha untuk mengetahui pelaksanaan penilaian guru PAUD di Aceh Utara.

\section{METODOLOGI PENELITIAN}

Penelitian ini menggunakan metode survey dengan melibatkan Responden berjumlah 70 guru PAUD di Aceh Utara. Instrumen penelitian menggunakan angket. Data yang 
dikumpulkan analisis secara deskriptif yaitu frekuensi dan persentase.

\section{HASIL PENELITIAN DAN \\ PEMBAHASAN \\ Profil Responden}

Berikut ini merupakan hasil angket berdasarkan demografi responden seperti yang digambarkan pada tabel 1

Tabel 1. Profil responden guru PAUD di Aceh Utara

\begin{tabular}{llcc}
\hline Profil Responden & Frekuensi & Persentase \\
\hline Jenis Kelamin & Lelaki & 0 & $0.00 \%$ \\
& Perempuan & 70 & $100 \%$ \\
Usia & $<20$ Tahun & 3 & $4.28 \%$ \\
& 20-30 & 23 & $32.85 \%$ \\
& Tahun & & $58.57 \%$ \\
& 31-40 & 41 & $4.28 \%$ \\
& $>$ Tahun Tahun & 3 & $20.00 \%$ \\
Pendidikan & Diploma & 14 & $78.65 \%$ \\
& Sarjana & 55 & $1.40 \%$ \\
& Lainnya & 1 & $15.71 \%$ \\
Pengalaman & $\leq 10$ Tahun & 11 & \\
Mengajar & & & \\
& $>10$ Tahun & 59 & \\
\hline
\end{tabular}

Tabel 1 menunjukkan semua responden (guru PAUD) berjenis perempuan $(100 \%)$. Dari aspek umur, 3 orang guru $(4.28 \%)$ berumur 20 tahun ke bawah, 23 (32.85\%) guru berumur 20-30 tahun, 41 guru $(58.57 \%)$ berumur $30-40$ tahun, dan 3 orang guru $(4.28 \%) 40$ tahun ke atas. Segi kelayakan akademik, 14 orang guru (20\%) mempunyai ijazah diploma, 55 orang $(78.6 \%)$ mempunyai ijazah sarjana dan selebihnya 1 orang guru $(1.4 \%)$ mempunyai ijazah selain sarjana dan diploma. Dari aspek pengalaman mengajar, 11 guru $(15.71 \%)$ berpengalaman mengajar dibawah 10 tahun, 59 guru $(84.29 \%)$ berpengalaman mengajar di atas 10 tahun.
Pelaksanaan Penilaian Autentik Guru PAUD

Pada bagian ini dijelaskan pelaksanaan penilaian autentik yang dilaksanakan oleh guru PAUD, seperti ditunjukkan pada tabel 2 .

Tabel 2. Pelaksanaan Penilaian Autentik Guru PAUD

\begin{tabular}{|c|c|c|c|}
\hline \multirow[b]{2}{*}{ No } & \multirow[b]{2}{*}{ Pernyataan } & \multicolumn{2}{|c|}{ Pelaksanaan } \\
\hline & & Menjalankan & $\begin{array}{c}\text { Tidak } \\
\text { Menjalankan }\end{array}$ \\
\hline 1 & $\begin{array}{l}\text { Merencanakan } \\
\text { penilaian autentik } \\
\text { sebelum } \\
\text { melaksanakan di } \\
\text { kelas }\end{array}$ & $28.57 \%$ & $71.43 \%$ \\
\hline 2 & $\begin{array}{l}\text { Menggunakan } \\
\text { pendekatan } \\
\text { pelbagai penilaian }\end{array}$ & $14.28 \%$ & $85.72 \%$ \\
\hline 3 & $\begin{array}{l}\text { Menggunakan } \\
\text { prinsip objektif, } \\
\text { terbuka dalam } \\
\text { melaksanakan } \\
\text { penilaian }\end{array}$ & $100 \%$ & 0 \\
\hline 4 & $\begin{array}{l}\text { Melaksanakan } \\
\text { penilaian sesuai } \\
\text { rencana }\end{array}$ & $14.28 \%$ & $85.72 \%$ \\
\hline 5 & $\begin{array}{l}\text { Melaksanakan } \\
\text { penilaian secara } \\
\text { berkesinambungan }\end{array}$ & $21.43 \%$ & $78.57 \%$ \\
\hline 6 & $\begin{array}{l}\text { Menggunakan } \\
\text { instrumen yang } \\
\text { dibuat sendiri }\end{array}$ & $28.57 \%$ & $71.43 \%$ \\
\hline 7 & $\begin{array}{l}\text { Merancang } \\
\text { penilaian } \\
\text { berdasarkan } \\
\text { blueprint } \\
\text { Kementerian } \\
\text { Pendidikan }\end{array}$ & $14.28 \%$ & $85.72 \%$ \\
\hline 8 & $\begin{array}{l}\text { Menggunakan } \\
\text { pelabelan dalam } \\
\text { memberikan } \\
\text { penilaian }\end{array}$ & $71.43 \%$ & $28.57 \%$ \\
\hline 9 & $\begin{array}{l}\text { Memberi ujian } \\
\text { tertulis }\end{array}$ & $85.72 \%$ & $14.28 \%$ \\
\hline 10 & $\begin{array}{l}\text { Memberi ujian } \\
\text { membaca }\end{array}$ & $85.72 \%$ & $14.28 \%$ \\
\hline 11 & $\begin{array}{l}\text { Memberi ujian } \\
\text { menghitung }\end{array}$ & $85.72 \%$ & $14.28 \%$ \\
\hline 12 & $\begin{array}{l}\text { Menggunakan } \\
\text { penilaian autentik }\end{array}$ & $14.28 \%$ & $85.72 \%$ \\
\hline 13 & $\begin{array}{l}\text { Menggunakan } \\
\text { pengamatan }\end{array}$ & $14.28 \%$ & $85.72 \%$ \\
\hline 14 & $\begin{array}{l}\text { Menggunakan } \\
\text { catatan harian }\end{array}$ & $14.28 \%$ & $85.72 \%$ \\
\hline 15 & $\begin{array}{l}\text { Menggunakan } \\
\text { portfolio }\end{array}$ & $14.28 \%$ & $85.72 \%$ \\
\hline 16 & $\begin{array}{l}\text { Menyimpan setiap } \\
\text { karya anak-anak }\end{array}$ & $28.57 \%$ & $71.43 \%$ \\
\hline 17 & $\begin{array}{l}\text { Menggunakan alat- } \\
\text { alat mendidik }\end{array}$ & $92.86 \%$ & $7.14 \%$ \\
\hline 18 & $\begin{array}{l}\text { Memberikan } \\
\text { deskripsi dalam } \\
\text { melaksanakan } \\
\text { penilaian di kelas }\end{array}$ & $14.28 \%$ & $85.72 \%$ \\
\hline 19 & $\begin{array}{l}\text { Melaksanakan } \\
\text { penilaian saat } \\
\text { aktivitas belajar }\end{array}$ & $28.57 \%$ & $71.43 \%$ \\
\hline 20 & $\begin{array}{l}\text { Memberikan } \\
\text { laporan kepada }\end{array}$ & $85.72 \%$ & $14.28 \%$ \\
\hline
\end{tabular}




\begin{tabular}{lll}
\hline 21 & $\begin{array}{l}\text { orang tua siswa } \\
\text { Melakukan } \\
\text { penilaian saat anak- } \\
\text { anak bermain } \\
\text { Melakukan } \\
\text { penilaian saat anak- } \\
\text { anak menyanyi } \\
\text { Melakukan } \\
\text { penilaian saat anak- } \\
\text { anak menari } \\
\text { Melakukan } \\
\text { penilaian saat anak- } \\
\text { anak menggambar } \\
\text { Dalam memberikan } \\
\text { penilaian saya } \\
\text { melihat } \\
\text { kemampuan anak } \\
\text { Dalam memberikan } \\
\text { penilaian saya } \\
\text { mempertimbangkan } \\
\text { umur }\end{array}$ & $7.14 \%$ \\
\hline
\end{tabular}

Tabel 2 di atas menunjukkan bahawa 50 orang guru $(71.43 \%)$ tidak membuat rencana penilaian, 10 guru $(14.28 \%)$ menggunakan pendekatan pelbagai penilaian, 60 guru $(85.72 \%)$ tidak melaksanakan penilaian sesuai rencana, 20 guru (28.57\%) yang membuat instrumen sendiri, 10 guru (14.28\%) merencanakan penilaian berdasarkan blue print Kementerian Pendidikan, dan sebanyak 50 guru (71.43\%) masih menggunakan angkaangka dalam memberikan hasil penilaian.

Dalam konteks pelaksanaan penilaian di kelas 60 guru $(85.72 \%)$ masih menggunakan ujian tulis, memberi ujian membaca, dan ujian menghitung. Sebanyak 60 guru $((85.72 \%)$ tidak menggunakan penilaian autentik. Untuk konteks penilaian autentik, sebanyak10 guru $(14.28 \%)$ melakukan pengamatan. Sedangkan sebanyak 10 guru (14.28\%) menggunakan catatan harian dan portfolio. Penilaian autentik semestinya dilakukan saat aktivitas belajar siswa tetapi kenyataannya hanya 20 guru (28.57) yang melaksanakan penilaian saat aktivitas siswa belajar. Sebanyak 5 guru (7.14\%) melaksanakan penilaian saat bermain, menyanyi, menari dan menggambar. Dalam konteks pelaporan kepada orang tua siswa sebanyak 60 guru $(85.72 \%)$ memberi laporan kepada orang tua siswa.
Berkaitan dengan penilaian guru

PAUD berdasarkan perkembangan kognitif anak usia dini, ditunjukkan pada tabel 3 .

Tabel 3. Penilaian Guru PAUD Berdasar kepada perkembangan kognitif anak

\begin{tabular}{|c|c|c|c|}
\hline \multirow{2}{*}{ No } & \multirow{2}{*}{ Pernyataan } & \multicolumn{2}{|c|}{ Pelaksanaan } \\
\hline & & Ya & Tidak \\
\hline 1 & $\begin{array}{l}\text { Menggunakan ujian } \\
\text { tulis }\end{array}$ & 85.72 & 14.28 \\
\hline 2 & $\begin{array}{l}\text { Menggunakan } \\
\text { penilaian autentik }\end{array}$ & 14.28 & 85.72 \\
\hline 3 & $\begin{array}{l}\text { Melakukan penilaian } \\
\text { saat bermain }\end{array}$ & 7.14 & 92.86 \\
\hline 4 & $\begin{array}{l}\text { Penilaian kepada } \\
\text { domain kognitif }\end{array}$ & 42.86 & 57.14 \\
\hline 5 & $\begin{array}{l}\text { Penilaian berbentuk } \\
\text { label }\end{array}$ & 71.43 & 28.57 \\
\hline 6 & $\begin{array}{l}\text { Penilaian bersifat } \\
\text { holistik }\end{array}$ & 14.28 & 85.72 \\
\hline 7 & $\begin{array}{l}\text { Hasil penilaian } \\
\text { berupa deskripsi }\end{array}$ & 28.57 & 71.43 \\
\hline 8 & $\begin{array}{l}\text { Penilaian saat } \\
\text { aktivitas siswa }\end{array}$ & 14.28 & 85.72 \\
\hline 9 & $\begin{array}{l}\text { Penilaian dilakukan } \\
\text { dengan pengamatan } \\
\text { gerakan halus }\end{array}$ & 14.28 & 85.72 \\
\hline 10 & $\begin{array}{l}\text { Penilaian dilakukan } \\
\text { dengan pengamatan } \\
\text { gerakan kasar }\end{array}$ & 14.28 & 85.72 \\
\hline 11 & $\begin{array}{l}\text { Penilaian dilakukan } \\
\text { dengan pengamatan } \\
\text { pada bahasa }\end{array}$ & 71.43 & 28.57 \\
\hline 12 & $\begin{array}{l}\text { Penilaian dilakukan } \\
\text { dengan pengamatan } \\
\text { keaktifan siswa }\end{array}$ & 28.57 & 71.43 \\
\hline 13 & $\begin{array}{l}\text { Mencatat dan } \\
\text { mendokumentasikan } \\
\text { perkara yang telah } \\
\text { dilakukan siswa }\end{array}$ & 28.57 & 71.43 \\
\hline 14 & $\begin{array}{l}\text { Penilaian terhadap } \\
\text { siswa dilakukan } \\
\text { secara kontinum, } \\
\text { melalui pengamatan }\end{array}$ & 14.28 & 85.72 \\
\hline
\end{tabular}

Berdasarkan tabel 3 diperoleh sebanyak 60 guru $(85.72 \%)$ masih menjalankan ujian tulis, 60 guru $(85.72 \%)$ tidak menjalankan penilaian autentik. Sebanyak 30 guru $(42.86 \%)$ penilaian lebih dominan kepada domain motorik, 50 guru (71.43\%) masih memberikan angka dalam setiap penilaian.

Hasil Kuesioner menunjukkan secara umum bahwa guru PAUD masih menggunakan ujian tertulis dalam penilaian. Guru masih memberi ujian membaca, dan ujian menghitung. Ujian tulis merupakan satu dari bagian penilaian tradisional. Guru masih menggunakan pelabelan dalam 
memberikan hasil penilaian atau penskoran.

Hasil penelitian ini didukung oleh pernyataan dari Nugiyantoro (2011), bahwa guru masih banyak menjalankan ujian tulis bagi anak-anak. Walaupun ujian tulis didapati dapat meramalkan pencapaian anak-anak di pendidikan anak usia diani dan di tahap awal pendidikan formal, penilaian ini dirasakan tidak betul-betul memenuhi kehendak dan tujuan penilaian diadakan dalam pendidikan awal anak-anak.

Padahal hal ini tidak sesuai dengan perkembangan anak-anak. Walaupun ujian tulis didapati dapat meramalkan pencapaian anak-anak di pendidikan awal anak-anak, penilaian seperti ini dirasakan tidak memenuhi kehendak dan tujuan penilaian yang diadakan dalam pendidikan anak usia dini. Malah, penilaian tulis akan membawa kepada kenegatifan bagi anakanak (Quay \& Steele 1998). Dalam ujian tulis terdapat ketidakadilan dari segi item ujian yang bersandarkan kepada norma dan pengalaman kumpulan tertentu dalam masyarakat yang boleh mempengaruhi kesahan sesuatu ujian (Stallman \& Pearson, 1990). Selaras dengan Brassard \& Boehm, 2008; Hainstock 2002 yang mengemukakan anak-anak secara mental belum siap membaca, menulis, berhitung hingga berusia paling tidak enam tahun.

$$
\text { Tingkat kemajuan dan }
$$

perkembangan anak-anak dapat diketahui apabila dilakukan penilaian yang berkelanjutan. Artinya, anak-anak akan tampak perkembangan kemampuannya manakala dilakukan pengamatan secara terus menerus setiap saat semasa anakanak melakukan aktivitas bermain dan belajar. Penilaian harus dilakukan secara harian, mingguan, dan bulanan tentang pelbagai perkara yang berkaitan dengan perkembangan anak-anak secara holistik. Hasil penilaian yang dilakukan kemudian dianalisis guna menggambarkan kemajuan dan perkembangannya (Musfiroh 2009). Penilaian dilaksanakan pada anak-anak bukanlah untuk membandingkan prestasi dan kemajuan perkembangan antara anak-anak melainkan untuk melihat perkembangan secara individual. Oleh itu, tidak ada juara kelas bagi anak-anak (Suyanto 2005). Beliau mengemukakan, di institusi pendidikan anak usia dini tidak diterapkan juara kelas atau peringkat kelas. Sebab anak-anak memiliki keunikan, bakat, minat dan kemampuan yang berbeda-beda secara individual.

Brassard dan Boehm (2008) penilaian pada pendidikan anak usia dini mestinya tidak berfokus pada hasil yang ingin dicapai oleh anak-anak sehingga guru kurang memberi perhatian yang cukup pada bagaimana anak-anak belajar, atau yang anak-anak perlukan yang berkait dengan konteks lingkungan anakanak. Penilaian yang membandingkan individu dengan individu lain sehingga pada akhirnya memberi pelabelan boleh membawa kenegatifan berlanjutan kepada anak-anak itu (Quay \& Steele 1998).

National Research Council (2009) Amerika Syarikat yang menyarankan untuk tidak memberikan ujian tulis kepada murid di Amerika Syarikat sebelum mereka duduk di kelas darjah 3 Sekolah Rendah. Seterusnya lembaga tersebut menyarankan penilaian performansi yang melekat pada penilaian autentik. Pendapat selaras dikemukakan Meisels (1995) bahwa penilaian yang tepat bagi murid awal anak-anak, murid 
sekolah rendah darjah satu dan dua adalah kaidah penilaian performansi yang melekat pada kurikulum atau yang sering disebut dengan authentic assessment.

\section{KESIMPULAN}

Hasil analisis kuesioner menunjukkan secara umum guru PAUD masih menggunakan ujian tulis dalam penilaian di sekolah. Guru masih memberi ujian membaca, dan ujian menghitung. Ujian tertulis merupakan satu dari bagian penilaian tradisional. Guru pun tidak membuat rencana penilaian autentik, tidak merencanakan penilaian berdasarkan cetak biru Kementerian pendidikan, serta masih menggunakan penskoran dalam memberikan hasil penilaian.

Oleh itu, perlunya para pengawas PAUD, kedua orang tua dan kementerian pendidikan dapat menjadikan hasil kajian ini sebagai langkah dalam mengambil tindakan terhadap persoalan yang ditemukan di lapangan dalam penelitian tersebut. Misalnya dengan memberi pelatihan tentang penilaian autentik, memberi penjelasan kepada orang tua siswa tentang pentingnya penilaian autentik dalam proses pembelajaran.

\section{DAFTAR PUSTAKA}

Aiman Ummu. (2015). Evaluasi Pelaksanaan Penilaian Autentik Dalam Kurikulum 2013. Thesis UIN Yogyakarta Tidak Dipublikasikan.

Arif, Saiful. (2014). Penerapan Penilaian Autentik Pada Mata Pelajaran PAI di SMPN 1 Pamekasan. Nuansa, 11 (2), p.234-265.

Brassard, M.R. \& Boehm, A.E. (2008). Preschool assessment : principles and practices. New York : The Guilford Press.

Cahyadi, F \& Purwandari, A. (2014). Penilaian Autentik Mata Pelajaran Matematika Kurikulum 2013 Guru Kelas IV Kota Semarang. Jurnal Universitas PGRI
Semarang Volume 4 Nomor 2 Desember 2014.

Gronlund, G. \& James, M. (2005). Focused observations: how to observe children for assessment and curriculum planning. St. Paul: Red Leaf Press.

Hainstock, E. G. (2002). Montessoeri untuk Anak Prasekolah.Jakarta: Pustaka Delaprasta

Jamaris, Martini. (2004). Perkembangan dan Pengembangan Anak Usia Taman Kanak-Kanak. Jakarta: Gramedia

Kementerian Pendidikan dan Kebudayaan Direktorat Jenderal Pendidikan Anak Usia Dini dan Pendidikan Masyarakat. 2015. Pedoman Penilaian Pembelajaran Pendidikan Anak Usia Dini.

Kementerian Pendidikan Nasional. (2010). Pedoman Penilaian Di Taman Kanak-Kanak. Tidak diterbitkan. Jakarta.

Koralek, D. (2004). Child and Program Assessment : Tool for Reflective Educators. Journal of The National Association for the Education of Young Children ( NEAYC ), Young Children, 59, 12-13.

Mahmudah, D. 2016. Implementasi Kurikulum (2013) Dalam Pendidikan Anak Usia Dini. Tesis Tidak Dipublikasikan: UIN Jogjakarta

Meisels, S. J. (1995). Performance assessment in early childhood education: The Work Sampling System. EDO-PS-95-6. Didapatkan semula pada 7 julai 2016 daripada http://ceep.crc.uiuc.edu/eecearchi ve/digests/1995/meiseI95 .html

Munawati, Susi. 2017. Pelaksanaan Penilaian Autentik DI Sekolah Dasar Negeri Pujokusuman I Yogyakarta. Jurnal Pendidikan 
Guru Sekolah Dasar Edisi 2 Tahun ke-6, p 174-183

Mueller. J. 2006. Authentic Assesment. North Central College. Tersedia: http://jonatan.muller.faculty.noctr 1.edu/toolbox/whatistis.html

Mulyasa. E. Prof. 2012. Manajemen PAUD. Bandung : Remaja Rosdakarya.

Musfiroh, T. 2005. Bermain Sambil Belajar dan Mengasah Kecerdasan. Jakarta: Depdiknas.

Nurjananto, N \& Kusumo, E 2015. Pengembangan Instrumen Penilaian Autentik Untuk Mengukur Kompetensi Peserta Didik Materi Senyawa Hidrokarbon. Jurnal Inovasi Pendidikan Kimia, 9(2), 1575 1584.

Nurgiyantoro, Burhan. 2011. Penilaian Otentik dalam Pembelajaran Bahasa. Yogyakarta: Gadjah Mada University Press.

National Research Council. 2009. Mathematics Learning in Early Childhood: Paths Toward Excellence and Equity. Washington, DC: The National Academies Press. https://doi.org/10.17226/12519

Paasche, C.L., Gorrill, L. \& Strom, B. 2004. Children with special needs in early childhood settings. New York : Thomson Delmar Learning.

Quay, L., \& Steele, D. 1998. Predicting children's achievement from teacher judgements: An alternative to standardized testing. Early Childhood and Development,9 (3), 207-218

Ruslan et al.2016. Kendala Guru Dalam Menerapkan Penilaian Autentik DI SD Kabupaten Pidie. Jurnal Pendidikan Guru Sekolah Dasar FKIP Unsyiah 1(1), 147-157

Suyanto, Slamet. 2005. Prinsip-prinsip pembelajaran anak usia dini. Makalah sarasehan pengembangan pembelajaran $d i$ $T K$ dan SD. Universitas Negeri Jogjakarta

Stallman, A. C., \& Pearson, P. D. 1990. Formal measures of early literacy. Dalam L. M.Morrow \& J. K. Smith (Eds.), Assessment for instruction in early literacy.Englewood Cliffs, NJ: Prentice-Hall, pp.7-44

Stiggins, R. J. 1994. Student-centered classroom assessment. New York: Merrill.

Sujati.2013. Pengembangan Instrumen Penilaian Otentik dan Validasinya. Proceeding Seminar Nasional Psikometri, PGSD Karang Malang Yogyakarta.

Shamsuri, S. 2008. Memahami penilaian cara mudah. Klang: DSS Publishing Enterprise. 